\title{
Selectivity of organic compounds to the egg parasitoid Telenomus remus Nixon (Hymenoptera: Plastygastridae)
}

\section{Seletividade de compostos orgânicos ao parasitoide de ovos Telenomus remus Nixon (Hymenoptera: Platygastridae)}

\author{
Débora Mello da Silva ${ }^{1 *}$; Adeney de Freitas Bueno ${ }^{2}$; Karine Andrade ${ }^{3}$; Cristiane \\ dos Santos Stecca ${ }^{4}$; Pedro Manuel Oliveira Janeiro Neves ${ }^{5}$; Flávio Moscardi ${ }^{6}$
}

\begin{abstract}
The selectivity of insecticides, bio-protective mixtures, and biofertilizers used in organic soybean production was evaluated for adults and pupae of the egg parasitoid Telenomus remus Nixon (Hymenoptera: Platygastridae) under laboratory conditions in accordance with protocols proposed by the International Organization for Biological Control (IOBC). The products sprayed (dosage/180L of water) were: 1) Baculovírus anticarsia 140x109 cpi; 2) Bacillus thuringiensis 16.8g; 3) Azadirachtin-A, azadirachtin-B, nimbina and salamina 9.6 ppm; 4) Rotenoids 4 liters; 5) Nitrogen 1.3\%, phosphorus $3.0 \%$ and total organic carbon $8.0 \% 3$ liters; 6) Sodium silicate 2\% 4 liters; 7) Copper 7\% + calcium $3.3 \% 1.8$ liters; 8) Sulfur 20\% + quicklime 10\% 1.8 liters; 9) Chlorpyrifos 384g (positive control); 10) Distilled $\mathrm{H}_{2} \mathrm{O}$ (negative control). The results of experiments using pupae indicate that the organic compounds were classified as harmless (Class 1), except for the copper 7\% + calcium 3.3\% and sulfur $20 \%+$ quicklime $10 \%$, which were classified as slightly harmful (Class 2 ). The contact bioassay with adults showed that all products were classified as harmless (Class 1). Only chlorpyrifos (384g) was classified as harmful (Class 4) for both stages of the parasitoid. However, the use of this product (chlorpyrifos) is not permitted in organic farming, and even in conventional farming is recommended, where feasible, replacement of the product with one compatible with the preservation of T. remus in nature. Thus, the products tested and used in organic soybean production were considered compatible with the parasitoid eggs of T. remus.
\end{abstract}

Key words: Biological control, IPM, sustainability, toxicity

\section{Resumo}

A seletividade de diferentes inseticidas, caldas fitoprotetoras e biofertilizantes utilizados na produção de soja orgânica foi avaliada sobre adultos e pupas do parasitoide de ovos Telenomus remus Nixon (Hymenoptera: Platygastridae) em condições de laboratório, de acordo com protocolos propostos pela Organização Internacional para o Controle Biológico (IOBC). Os produtos (dose/180 L de água) foram: 1) Baculovírus anticarsia $140 \times 10^{9} \mathrm{cpi}$; 2) Bacillus thuringiensis $16,8 \mathrm{~g}$; 3) Azadirachtin-A, azadirachtin-B, nimbina e salamina 9,6ppm; 4) Rotenoides 4\% 4 litros; 5) Nitrogênio 1,3\%, fósforo 3,0\% e carbono

${ }^{1}$ Bolsista Pós-Doutorado, CAPES-Fundação Araucária, Instituto Agronômico do Paraná, IAPAR, Londrina, PR, Brasil. E-mail: deboramellosilva@gmail.com

2 Eng $^{\mathrm{O}} \mathrm{Agr}^{\circ}$, Dr. em Entomologia, Pesquisador A da EMBRAPA Soja, Londrina, PR, Brasil. E-mail: adeney.bueno@embrapa.br

${ }^{3} \mathrm{Eng}^{\mathrm{O}} \mathrm{Agr}^{\circ}$ M.e em Agronomia, Universidade Estadual de Londrina, UEL, Londrina, PR, Brasil. E-mail: karineandrade16@ hotmail.com

${ }^{4}$ Eng $^{\mathrm{O}} \mathrm{Agr}^{\mathrm{o}}, \mathrm{Dr}^{\mathrm{a}}$ em Agronomia, UEL, Londrina, PR. E-mail: cristiane_stecca@yahoo.com.br

${ }^{5}$ Eng $^{\circ} \mathrm{Agr}^{\circ}$, Dr. em Entomologia, Bolsista PQ1/ CNPq, Prof. Adjunto, Dept ${ }^{\circ}$ de Agronomia, Centro de Ciências Agrárias, UEL, Londrina, PR, Brasil. E-mail: pedroneves@uel.br

${ }^{6}$ In memoriam

* Author for correspondence 
orgânico total 8,0\% 3 litros; 6) Silicato de Sódio 2\% 4 litros; 7) Cobre 7\% + Cálcio 3,3\% 1,8 litros; 8) Enxofre 20\% + cal virgem 10\% 1,8 litros; 9) Clorpirifós 384g (controle positivo); 10) Água destilada (controle negativo). O resultado dos experimentos para a fase de pupa indicaram que os compostos orgânicos foram classificados como inócuos (classe 1), exceto para as misturas cobre $7 \%+$ cálcio 3,3\% e enxofre $20 \%+$ cal virgem $10 \%$, que foram classificados como levemente nocivos (classe 2 ). O teste de contato com os adultos mostrou que todos os produtos foram classificados como inócuos (classe 1). Somente clorpirifós foi classificado como nocivo (classe 4) para ambas as fases de desenvolvimento do parasitoide. Entretanto, a utilização deste produto (clorpirifós) não é permitida em cultivos orgânicos, e mesmo na agricultura convencional recomenda-se, quando viável, a substituição desse produto por outro compatível com a preservação de T. remus na natureza. Sendo assim, os produtos testados e utilizados na produção orgânica de soja foram considerados compatíveis com o parasitoide de ovos T. remus.

Palavras-chave: Controle biológico, MIP, toxicidade, viabilidade

\section{Introduction}

Organic farming has grown rapidly throughout the world during the last decade. According to surveys conducted by the Research Institute of Organic Agriculture (FiBL) and the International Foundation for Organic Agriculture (IFOAM), there are around 37.2 million hectares cultivated with organic crops worldwide (WILLER et al., 2013). The high demand for pesticide-free food and the high prices of organic products have fostered an increase in the production and marketing in this market segment (CAVIGELLI et al., 2013; MCBRIDE; GREENE, 2009). In addition to these economic benefits, organic farming can help mitigate the negative impacts of traditional agriculture, such as pesticide residues in food and water; improve soil quality and organic matter; and increase biodiversity, especially of beneficial insects such as biological control agents (LAIRON, 2010; MCBRIDE; GREENE, 2009).

In order to achieve profitable organic soybean yields, it is important to use pesticides which are not only effective against pests and diseases but also meet the requirements for organic certification (CAVIGELLI et al., 2013; ZEHNDER et al., 2007). Organic pesticides, although formulated for use in organic farming, are not always harmless to natural enemies, and might therefore endanger the success of biological control strategies (SIDI et al., 2012). Less harmful pesticides should always be chosen over the more harmful ones, since they allow the control of the target pest without negatively affecting beneficial arthropods in the environment (BACCI et al., 2007; BUENO; FREITAS, 2004).

In organic farming, biological control using parasitoids can replace old chemical control strategies that are not permitted in organic production (VAN LENTEREN; BUENO, 2003). Inundative releases of the egg parasitoid Telenomus remus Nixon (Hymenoptera: Platygastridae) have been used in South and Central American countries, reaching up to $90 \%$ parasitism on Spodoptera eggs (FERRER, 2001). This is a successful example of parasitoid use and has been identified by different researchers as a promising alternative to chemical control, while also helping to reduce the negative effects of intensive agriculture on the environment and being economically viable for soybean growers (BUENO et al., 2008; VAN LENTEREN; BUENO, 2003).

It is important to note in this context that economically important pests can be controlled by parasitoids such as T. remus (BUENO et al., 2008), especially in organic farming, in which chemical control is not allowed. Minerals and other biological insecticides can also be used in organic farming to facilitate pest control (ZEHNDER et al., 2007). However, growers must follow International Foundation for Organic Agriculture (IFOAM) recommendations in order to use such biological insecticides. Possible effects of those biological insecticides to the environment and to human or animal health should be taken into consideration (IFOAM, 2005). Although there are criteria for 
using these products of organic and mineral origin, there are few studies on their effects on beneficial arthropods, such as T. remus or other egg parasitoids. This knowledge is crucial to integrate these different pest management strategies (ZEHNDER et al., 2007). Therefore, this study evaluated the selectivity to the egg parasitoid T. remus of compounds used in organic soybean production.

\section{Materials and Methods}

The experiments were conducted in the laboratory under controlled conditions $\left(25 \pm 1{ }^{\circ} \mathrm{C}\right.$, $70 \pm 10 \% \mathrm{RH}$, and photoperiod of $14 / 10 \mathrm{~h} \mathrm{~L} / \mathrm{D}$ ) in a randomized design, with 10 treatments and five repetitions according to standard protocols by the International Organisation for Biological Control (IOBC) as described by Hassan (1992). The selectivity of the products used in organic agriculture to natural enemies was assessed using the maximum recommended dosage for the control of pests and diseases in the production of organic soybean.

Bioassay with pupae. Cardboard squares (approximately $1 \mathrm{~cm} 2$ ) containing Spodoptera frugiperda J. E. Smith (Lepidoptera: Noctuidae) laying eggs previously parasitized by $T$. remus were sprayed with various treatments (Table 1) nine days after parasitism using a Potter Tower regulated to a pressure of $1.5 \mathrm{Kg} / \mathrm{cm}^{-2}$, ensuring a deposit of 1.25 $\pm 0.25 \mathrm{mg} \mathrm{cm}^{-2}$ (HASSAN, 1992; MANZONI et al., 2007). The applied volume was controlled using an electronic precision scale before and after spraying treatments (BUENO, 2001). Then, the cards were maintained under environmental conditions for about two hours to eliminate excess moisture. After they were dried, they were placed in contact cages consisting of two glass plates separated by an aluminum frame with ventilation holes (DEGRANDE et al., 2002). Once the parasitoids emerged, cards containing fresh S. frugiperda eggs (less than 24 hours old) were placed in the cages for two consecutive days in order to evaluate the parasitism capacity of the surviving parasitoid females (CARMO et al., 2010). The viability of the sprayed pupae (\%), calculated as the number of adults emerging from the sprayed eggs, and the parasitism and parasite viability of the $F_{1}$ generation (offspring of the treated pupae) were analyzed.

Bioassay with adults. Treatments were applied directly onto glass plates $(13 \mathrm{~cm} \times 13 \mathrm{~cm})$ using a Potter Tower, following the same methodology described for the bioassay with pupae (BUENO, 2001). When dry, the plates were set in aluminum frames, using the cage arrangement described by Degrande et al. (2002). Vials containing the parasitoids were then connected to the cages, exposing the parasitoids to the glass plates (CARMO et al., 2010). Twenty-four hours after parasitoid release into the cages, numbered cards containing S. frugiperda egg masses (400 eggs) and honey droplets were inserted. A second card was placed inside each cage $24 \mathrm{~h}$ after the placement of the first. Since viable eggs were used in order to avoid any change in T. remus behavior, the trials needed to be stopped on the third day to prevent $S$. frugiperda from hatching.

Evaluations and analyses. Parasitism (\%) and parasitoid emergence (\%) were evaluated. The data were tested for normality (SHAPIRO; WILK, $1965)$ and homogeneity of variance (BURR; FOSTER, 1972) of treatments, and if necessary were transformed into arcsin $\sqrt{X / 100}$ to allow for an ANOVA. The means were compared using Tukey's test ( $5 \%$ probability). The reduction in parasitism relative to the control treatment (distilled water) was computed using the equation: $\mathrm{E}(\%)=$ $(1-\mathrm{Vt} / \mathrm{Vc}) \times 100$, in which $\mathrm{E}(\%)$ is the percent reduction in parasitism; $\mathrm{Vt}$ is the mean parasitism for the treatment tested; and $\mathrm{Vc}$ is the mean parasitism observed for the control treatment. The products were classified according to the IOBC standards, as follows: Class 1, harmless $(\mathrm{E}<30 \%)$; Class 2, slightly harmful $(30 \% \leq \mathrm{E} \leq 79 \%)$; Class 3 , moderately harmful $(80 \% \leq \mathrm{E} \leq 99 \%)$; and Class 4, harmful (E > 99\%) (CARMO et al., 2010; HASSAN, 1992). 
Table 1. Treatments tested against pupae and adults of the egg parasitoid Telenomus remus (Hymenoptera: Platygastridae).

\begin{tabular}{|c|c|c|c|}
\hline Commercial Product & Formulation & Provider/manufacturer & $\begin{array}{c}\text { Dosage } \\
180 \mathrm{~L} \\
\mathrm{H}_{2} \mathrm{O} \\
\end{array}$ \\
\hline Baculovírus $\mathrm{AEE}^{\circledR}$ & Baculovírus anticarsia $7 \times 10^{9}$ cpi.g $^{-1}$ & $\begin{array}{c}\text { Embrapa Employees Association } \\
\text { AEE/CNPSoja }\end{array}$ & $\begin{array}{c}140 \times 10^{9} \\
\mathrm{cpi}\end{array}$ \\
\hline Dipel $^{\circledR}$ & Bacillus thuringiensis $33.6{\mathrm{~g} . \mathrm{l}^{-1}}^{-1}$ & $\begin{array}{l}\text { Sumitomo Chemical of Brazil } \\
\text { Representatives Ltd }\end{array}$ & $0.5 \mathrm{~L}$ \\
\hline Neemseto $^{\circledR}$ & $\begin{array}{l}\text { Neem oil (Azadirachtin-A, } \\
\text { Azadirachtin-B, Nimbina and Salamina } \\
\left.2.389 \mathrm{ppm}^{-\mathrm{l}^{-1}}\right)\end{array}$ & Cruangi Neem of Brazil Ltd & $4.0 \mathrm{~L}$ \\
\hline Arrast $^{\circledR}$ & Deguelia utilis extract (Rotenoids 4\%) & $\begin{array}{l}\text { Humânita Chemical and } \\
\text { Pharmaceutical S.A. }\end{array}$ & $4.0 \mathrm{~L}$ \\
\hline Fish-Fertil Indure $^{\circledR}$ & $\begin{array}{l}\text { Derivatives from crustaceans shells } \\
\text { (nitrogen } 1.3 \% \text {, phosphorus } 3.0 \% \text { and } \\
\text { total organic carbon } 8.0 \% \text { ) }\end{array}$ & $\begin{array}{l}\text { Fish Industries and Commerce } \\
\text { of Fertilizers Ltd }\end{array}$ & $3.0 \mathrm{~L}$ \\
\hline Na Silicate & Sodium silicate $2 \%$ dissolved in $\mathrm{H}_{2} \mathrm{O}$ & * & $4.0 \mathrm{~L}$ \\
\hline Borda-Ferti $\mathrm{pH} 7^{\circledR}$ & Copper $7 \%+$ Calcium $3.3 \%$ & $\begin{array}{l}\text { Planalquímica of Brazil } \\
\text { Chemical Industry Ltd }\end{array}$ & $1.8 \mathrm{~L}$ \\
\hline Lime-sulfur mixture & $\begin{array}{c}\text { Sulfur } 20 \%+\text { quicklime } 10 \% \text { (POLITO, } \\
2000)\end{array}$ & $*$ & $1.8 \mathrm{~L}$ \\
\hline Lorsban $480 \mathrm{CE} \circledast$ & chlorpyrifos $480 \mathrm{~g} .1^{-1}$ & $\begin{array}{l}\text { Dow AgroSciences Industrial } \\
\text { Ltd }\end{array}$ & $0.8 \mathrm{~L}$ \\
\hline Control & Distilled $\mathrm{H}_{2} \mathrm{O}$ & - & - \\
\hline
\end{tabular}

*Mixture prepared at EMBRAPA Soybean to be used in the experiment.

\section{Results}

A statistical difference $(\mathrm{p}<0.0001)$ was observed in the evaluated parameters both in the pupal and adult trials (Tables 1 and 2), indicating the influence of the tested products on the emergence of pupae, parasitism capacity, and viability of $T$. remus on $S$. frugiperda eggs. T. remus pupae in the Baculovírus anticarsia treatment group had the highest viability, which remained above $90 \%$, similar to that of the negative control $\left(\mathrm{H}_{2} \mathrm{O}\right)$. The other treatments, Bacillus thuringiensis, neem oil, derivatives from crustaceans, Na silicate, and sulfur $20 \%+$ quicklime $10 \%$, although having a slight reduction in parasitism, were considered harmless (Class 1) according to the IOBC classification, the same as for the Baculovírus anticarsia (Table 2). The lowest parasitoid emergence index (Table 2), excluding chlorpyrifos $(384 \mathrm{~g})$, was observed in the treatment with Deguelia utilis extract (58.98\%), which was classified as slightly harmful to parasitoids (Class 2).

T. remus parasitism in $S$. frugiperda eggs offered to females one day after emergence (DAE) remained above $99 \%$ for most of the treatments (Table 2) and did not differ from the negative control treatment $\left(\mathrm{H}_{2} \mathrm{O}\right)$, except for $\mathrm{Na}$ silicate and the sulfur $20 \%+$ quicklime $10 \%$, which were classified as harmless even though they reduced the parasitism of $T$. remus compared to water treatment. The viability of parasitism for most treatments did not differ from that of chlorpyrifos (384g); only the sulfur $20 \%+$ quicklime $10 \%$ reduced the viability of parasitoids 
(Table 2) and was rated as slightly harmful (Class

2). The other treatments were classified as harmless to T. remus (Class 1).

Eggs of $S$. frugiperda offered two DAE to $T$. remus pupae had lower levels of parasitism than the negative control $\left(\mathrm{H}_{2} \mathrm{O}\right)$ in the treatments derived from crustaceans and the sulfur $20 \%+$ quicklime $10 \%$ (Table 2). The viability of parasitism was higher in eggs offered to adults from the Baculovírus anticarsia treatment (82\%); other products caused a reduction in viability when compared to the negative control $\left(\mathrm{H}_{2} \mathrm{O}\right)$ (Table 2$)$. Despite the viability reductions, all treatments were classified as harmless to $T$. remus (Class 1), except for chlorpyrifos (384g), which was classified as harmful (Class 4).

In bioassays with $T$. remus adults, $S$. frugiperda eggs inserted one day after application (DAA) of the showed reduced parasitism by $T$. remus in the treatments with Deguelia utilis extract and derivatives of crustaceans, while others (B. anticarsia, azadirachtin, B. thuringiensis, copper $7 \%+$ calcium $3.3 \%$ and the sulfur $20 \%+$ quicklime $10 \%$ ) were similar to the negative control $\left(\mathrm{H}_{2} \mathrm{O}\right)$ (Table 3). The treatments with Baculovírus anticarsia, B. thuringiensis, neem oil, Deguelia utilis extract and derivatives of crustaceans had the highest viability rates (Table 3). Treatment with $\mathrm{Na}$ silicate and sulfur $20 \%+$ quicklime $10 \%$ reduced the viability of parasites by approximately $29 \%$ and $15 \%$, respectively, compared to the control $\left(\mathrm{H}_{2} \mathrm{O}\right)$. However, even with the reduction in viability, all treatments were classified as harmless (Class 1), except for chlorpyrifos (384g), which was slightly harmful (Class 2).

Spodoptera frugiperda eggs offered to T. remus adults two days after the applications were parasitized to a lesser extent only in the treatments with neem oil, Deguelia utilis extract, and derivatives of crustaceans (Table 3). The remaining products did not influence the parasitism, similar to the negative control. The viability of eggs parasitized by adults who were exposed to the products was similar to the negative control in the treatments with Baculovírus anticarsia, derivatives of crustaceans, Deguelia utilis extract, and the sulfur $20 \%+$ quicklime $10 \%$, remaining above $79 \%$. The other products, $B$. thuringiensis, neem oil, Na silicate, and the copper $7 \%+$ calcium $3.3 \%$, reduced the viability of the parasitoid. Unlike chlorpyrifos (384g) (Class 4), all of these products were harmless (Class 1) to $T$. remus. 


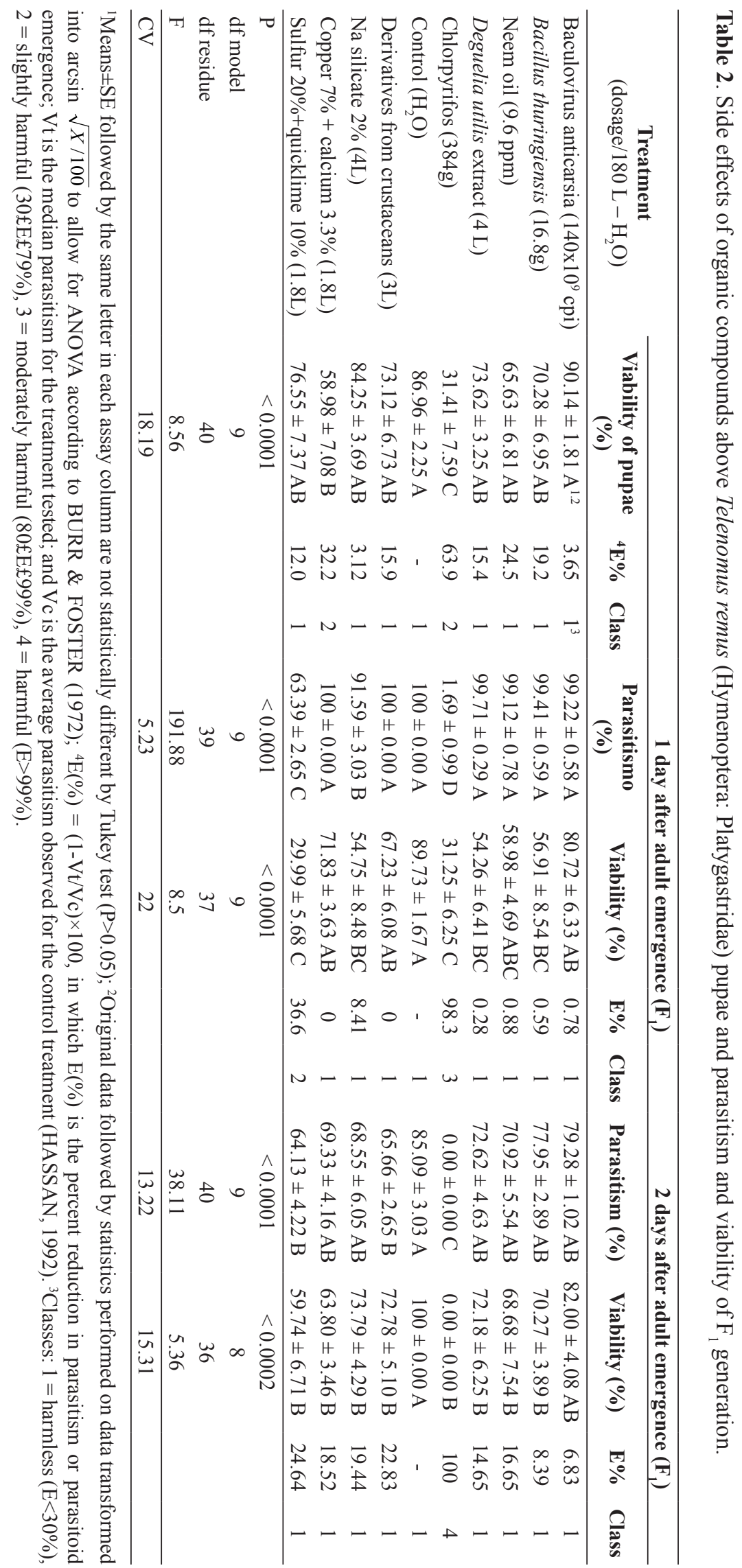




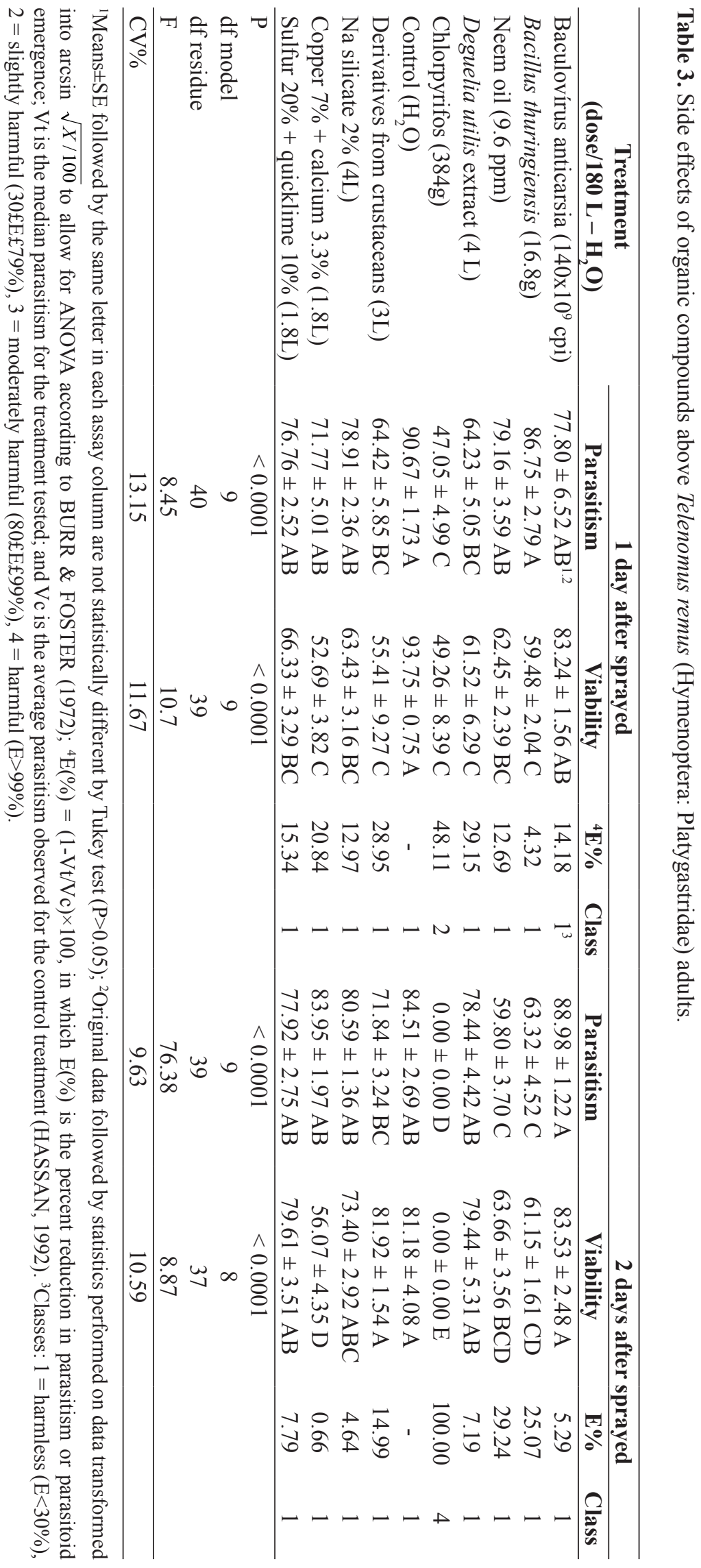




\section{Discussion}

In this study, only chlorpyrifos (384g) was able to penetrate the pupae and affect the development of T. remus. It is possibly because pupae is the most resistant stage to pesticides due to the sheltering offered by its cocoon (BUENO et al., 2008; CARMO et al., 2010; SANTOS et al., 2006). Chlorpyrifos works via the phosphorylation of the enzyme acetylcholinesterase (AChE) in the nerve endings, which reduces available AChE and increases activity in the organs due to excess acetylcholine, which similarly affects both beneficial insects and pests. Several surveys have reported low selectivity of organophosphates in Integrated Pest Management (IPM) (BUENO et al., 2008; TOSCANO et al., 2012.).

In the bioassays with pupae and adults of T. remus, parasitism and its viability were not affected by Baculovírus anticarsia, which is used to combat the velvetbean caterpillar, Anticarsia gemmatalis. The same selectivity was reported for B. thuringiensis, also used to control lepidopterans, but with faster mortality of its target. The harmless effect of these compounds is probably because these entomopathogens (viruses and bacteria) require that the $\mathrm{pH}$ of the midgut of insects is appropriate for the activation of their toxins, which does not occur in parasitoids (KNUTSON, 1998; TAKADA et al., 2001; VALICENTE; TUELHER, 2009).

Different plant extract-based products are successfully used as insecticides (ISMAN, 2006; VENZON et al., 2008). However, some studies show that plants such as neem oil, Azadirachta indica, adversely affect the oviposition, fecundity, feeding, and growth of various beneficial insects (GONCALVES-GERVASIO; VENDRAMIM, 2004; MORDUE; NISBET, 2000; SCHMUTTERER, 1990). Differently, one of the first studies on the selectivity of natural products was carried out in India by Joshi et al. (1982), who sprayed aqueous solutions of $2 \%$ neem seed on Spodoptera litura Fabricius (Lepidoptera:
Noctuidae) eggs, which did not negatively impact T. remus parasitism, but did change the longevity and fecundity of adult parasitoids. The reduction in the viability of $T$. remus parasitism during the pupal stage reported in our study may be because the concentration of azadirachtin was twice that used by Joshi et al. (1982). Commercial formulations of neem lack standardization in the amount of active ingredient (azadirachtin), which can cause differences in selectivity and product performance.

Deguelia utilis extract, used for formulation of Arrast ${ }^{\circledR}$, reduced the viability of parasitism when sprayed on pupae and adults. This reduction can be attributed to the mechanism of action of rotenone, which is the active ingredient of this plant (MOREIRA et al., 2005). Rotenone is a very toxic compound and acts against a wide range of insects by blocking the electron transport chain and preventing energy production in the mitochondria (HOLLINGWORTH et al., 1994). The use of rotenone as an insecticide is limited in the production of organic foods due to its side effects in humans (ISMAN, 2006). However, studies on the side effects of these extracts on non-target organisms are scarce.

Bio-protective mixtures such as the copper 7\%+ calcium $3.3 \%$ and the sulfur $20 \%+$ quicklime $10 \%$ are being increasingly used by small farmers of organic crops (GONÇALVES et al., 2004; VENZON et al., 2005) as a source of nutrients for plants and for fighting diseases (POLITO, 2001; SILVA; CARVALHO, 2000). There are reports that some bio-protective mixtures can also act as insecticides; however, the effects of these products on natural enemies must still be determined by larger studies (EFROM et al., 2011; GONÇALVES et al., 2004). The sulfur $20 \%+$ quicklime $10 \%$ and copper $7 \%$ + calcium $3.3 \%$ had negative effects on T. remus, reducing its parasitism, however, the mechanisms of action of these bio-protective mixtures are not well known. Silva (2005) and Dal Soglio et al. (2007) showed that the lime-sulfur mixture also had a negative influence on Apis mellifera (Hymenoptera: 
Apidae), a pollinator insect in citrus orchards of the same order as T. remus. The authors attributed this impact to the number of spray applications made during the study period. According to Polito (2000), the toxic effect of the lime-sulfur mixture is due to the reaction between its components, water and carbon dioxide, to form hydrogen sulfide, which makes the syrup insecticidal.

Other products used in organic agriculture are biofertilizers, such as derivatives of crustaceans and $\mathrm{Na}$ silicate. Derivatives from crustaceans, which is applied to leaves, comes from the natural enzymatic fermentation of marine fish, enriched with chitosan from the shells of crustaceans. This product acts as a regulator of the nutritional balance of the plants, improving photosynthetic rate (DI PIERO; GARDA, 2008). Another benefit reported by the manufacturers of this biofertilizer is that chitosan induces genes involved in plant resistance to disease and pests (DI PIERO; GARDA, 2008). In this study, derivatives from crustaceans reduced the parasitism and viability of $T$. remus in both pupa and adults, as did $\mathrm{Na}$ silicate (2\%). Studies show that silicate in plants increases cell wall strength and the number of plant trichomes, which protect the plant against attack by pathogens such as fungi and insects (GOUSSAIN et al., 2002; MORAES et al., 2004). Therefore, due to their negative effects on $T$. remus, caution is required regarding the dosage and concentration of these products when using them as biofertilizers.

Assays for the pupal stage were performed under extreme spray exposure to the recommended doses for soybean, and the products that were considered selective and harmless to the parasitoids will therefore be so in any field conditions to which they are exposed. According to Hassan (1992), products that have been classified as slightly harmful, moderately harmful, or harmful should be re-tested to verify the effects on parasitoids in field conditions. Adult parasitoids, despite having higher mobility, may be more exposed to the negative effects of spray products used in pest control (BUENO et al., 2008), and it is therefore important to study these products to inform decisions on their use in the IPM.

\section{References}

BACCI, L.; CRESPO, A. L. B.; GALVAN, T. L.; PEREIRA, E. J. G.; PICANÇO, M. C.; SILVA, G. A.; CHEDIAK, M. Toxicity of insecticides to the sweetpotato whitefly (Hemiptera: Aleyrodidae) and its natural enemies. Pest Management Science, New York, v. 63, n. 7, p. 699-706, 2007.

BUENO, A. F.; BUENO, R. C. O. F.; PARRA, J. R. P.; VIEIRA, S. S. Effects of pesticides used in soybean crops to the egg parasitoid Trichogramma pretiosum. Ciência Rural, Santa Maria, v. 38, n. 6, p. 1495-1503, 2008.

BUENO, A. F.; FREITAS, S. Effect of the insecticides abamectin and lufenuron on eggs and larvae of Chrysoperla externa under laboratory conditions. BioControl, Dordrech, v. 49, n. 3, p. 277-283, 2004.

BUENO, A. F. Seletividade de inseticidas e acaricidas utilizados na cultura dos citros para Chrysoperla externa (Hagen, 1861) (Neuroptera: Chrysopidae) em condições de laboratório. 2001. (Dissertação de Mestrado) Universidade Estadual de São Paulo, Jaboticabal.

CARMO, E. L.; BUENO, A. F.; BUENO, R. C. O. F. Pesticide selectivity for the insect egg parasitoid Telenomus remus. BioControl, Dordrech, v. 21, n. 55, p. 455-464, 2010.

CAVIGELLI, M. A.; MIRSKY, S. B.; TEASDALE, J. R.; SPARGO, J. T.; DORAN, J. Organic management systems to enhance ecosystem services. Renewable Agriculture and Food Systems, Cambridge, v. 28, n. 2, p. 145-159, 2013.

DAL SOGLIO, F. K.; SILVA, F. F. da; JESUS, C. R.; REDAELLI, L. R.; KOLLER, O. C.; GREVE, C.; JAHNKE, S. M.; SCHMIDT, J.; PRADE, C.; FOCCHI, S. S.; SANTOS, J. C. A. Desenvolvimento de tecnologias apropriadas para a produção de mudas e frutas cítricas em sistema familiar de produção. Revista Brasileira de Agroecologia, Porto Alegre, v. 2, n. 1, p. 98-101, 2007.

DEGRANDE, P. E.; REIS, P. R.; CARVALHO, G. A.; BELARMINO, L. C. Metodologia para avaliar o impacto de pesticidas sobre inimigos naturais. In: PARRA, J. R. P.; BOTELHO, P. S. M.; CORRÊA-FERREIRA B. S.; BENTO. J. M. S. (Ed.). Controle biológico no Brasil: parasitóides e predadores. São Paulo: Manole, 2002. p. 75-81. 
DI PIERO, R. M.; GARDA, M. V. Quitosana reduz a severidade da antracnose e aumenta a atividade de glucanase em feijoeiro-comum. Pesquisa Agropecuária Brasileira, Brasília, v. 43, n. 9, p. 1121-1128, 2008.

EFROM, C. F. S.; REDAELLI, L. R.; MEIRELLES, R. N.; OURIQUE, C. B. Laboratory evaluation of phytosanitary products used for control of the South American fruit fly, Anastrepha fraterculus, in organic farming. Crop Protection, Kidlington, v. 30, n. 7, p. 1162-1167, 2011.

FERRER, F. Biological of agricultural insect pest in Venezuela; advances, achievements, and future perspectives. Biocontrol News and Information, Heidelberg, v. 22, n. 3, p. 67-74, 2001.

GONCALVES-GERVASIO, R. C. R.; VENDRAMIM, J. D. Efeito de extratos de Meliaceas sobre o parasitoide de ovos Trichogramma pretiosum Riley (Hymenoptera: Trichogrammatidae). Neotropical Entomology, Londrina, v. 33, n. 5, p. 607-612, 2004.

GOUSSAIN, M. M.; MORAES, J. C.; CARVALHO, J. G.; NOGUEIRA, N. L.; ROSSI, M. L. Efeito da aplicação de silício em plantas de milho no desenvolvimento biológico da lagarta-do-cartucho Spodoptera frugiperda (J. E. Smith) (Lepidoptera: Noctuidae). Neotropical Entomology, Londrina, v. 31, n. 2, p. 305-310, 2002.

HASSAN, S. A. Guideline for the evaluation of sideeffects of plant protection products on Trichogramma cacoeciae. In: (Ed.). Guidelines for testing the effects of pesticides on beneficial organisms: description of test methods. Dordrecht: IOBC/WPRS Bulletin, 1992. v. 15, p. 18-39.

ISMAN, M. B. Botanical insecticides, deterrents, and repellents in modern agriculture and an increasingly regulated world. Annual Review Entomology, Stanford, v. 51, n. 1, p. 45-66, 2006.

JOSHI, B. G.; RAMAPRASAD, G.; SITARAMAIAH, S. Effect of neem seed kernel suspension on Telenomus remus, an egg parasite of Spodoptera litura. Phytoparasitica, Rehovot, v. 10, n. 1, p. 61-63, 1982.

KNUTSON, A. The Trichogramma manual. College Station: The Texas A \& M University System, 1998. 42 p.

LAIRON, D. Nutritional quality and safety of organic food. A review. Agronomy Sustainable Development, Heidelberg, v. 30, n. 1, p. 33-41, 2010. Available at: $<$ http://www.agronomy 3 journal.org/index. php?option $=$ com_articleeaccess $=$ doiedoi $=10.1051 /$ agro/2009019eItemid=129>. Accessed at: 9 feb. 2013.
MANZONI, C. G.; GRÜTZMACHER, A. D.; GIOLO, F. P.; HÄRTER, W. R.; CASTILHOS, R. V.; PASCHOAL, M. D. F. Seletividade de Agroquímicos utilizados na produção integrada de maçã aos parasitóides Trichogramma pretiosum Riley e Trichogramma atopovirilia Oatan e Platner (Hymenoptera: Trichogrammatidae). BioAssay, Londrina, v. 2, n. 1, p. 1-11, 2007.

MCBRIDE, W. D.; GREENE, C. The profitability of organic soybean production. Renewable Agriculture Food System, Cambridge, v. 24, n. 4, p. 276-284, 2009. Available at: <http://journals.cambridge.org/action/displ ayAbstract? fromPage $=$ onlineeaid $=6642460>$. Accessed at: 16 july 2013 .

MORDUE, L. A. J.; NISBET, A. J. Azadirachtin from the neem tree Azadirachta indica: its action against insects. Anais da Sociedade Entomológica do Brasil, Londrina, v. 29, n. 4, p. 615-632, 2000.

POLITO, W. L. Calda sulfocálcica, bordalesa e viçosa:os fitoprotetores no contexto da trofobiose. Agroecologia Hoje, Botucatu, v. 1, n. 3, p. 20-21, 2000.

Os fertiprotetores (calda sulfocálcica, calda bordalesa, calda Viçosa e outros) no contexto da trofobiose, In: HEIN, M. (Ed.). ENCONTRO DE PROCESSOS DE PROTEÇÃO DE PLANTAS: CONTROLE ECOLÓGICO DE PRAGAS E DOENÇAS. 1., 2001, Botucatu. Anais... Botucatu: Agroecológica, 2001. p. 75-89.

SHAPIRO, S. S.; WILK, M. B. An analysis of variance test for normality. Biometrika, Great Britain, v. 52, n. 3-4, p. 591-611, 1965.

SIDI, M. B.; TOUHIDUL ISLAM, M. D.; IBRAHIM, Y.; DZOLKHIFLI, O. Effect of insecticide residue and spray volume application of azadirachtin and rotenone on Trichogramma papilionis (Hymenoptera: Trichogrammatidae). International Journal of Agriculture e Biology, Faisalabad, v. 14, n. 5, p. 805-810, 2012.

SILVA, B. M.; CARVALHO, A. F. Novo supermagro: o biofertilizante. Viçosa: TA/ZM, 2000. 16 p.

SILVA, F. F. Espécies de moscas frugívoras (Diptera: Tephritidae e Lonchaeidae), quantificação de danos e avaliação de medidas para o seu manejo em pomares orgânicos de citros. 2005. Tese (Doutorado em Agronomia) - Universidade Federal do Rio Grande do Sul, Porto Alegre.

TAKADA, Y.; KAWAMURA, S.; TANAKA, T. Effects of various insecticides on the development of the egg parasitoid Trichogramma dendrolimi (Hymenoptera: Trichogrammatidae). Journal of Economy Entomology, Lanham, v. 94, n. 6, p. 1340-1343, 2001. 
TOSCANO, L. C.; CALADO FILHO, G. C.; CARDOSO, A. M.; MARUYAMA, W. I.; TOMQUELSKI, G. V. Impacto de inseticidas sobre Spodoptera frugiperda (Lepidoptera: Noctuidae) e seus inimigos naturais em milho safrinha cultivado em Cassilândia e Chapadão do sul, MS. Arquivos do Instituto Biológico, São Paulo, v. 79, n. 2, p. 223-231, 2012.

VAN LENTEREN, J. C.; BUENO, V. H. P. Augmentative biological control of arthropods in Latin America. BioControl, Dordrech, v. 48, n. 2, p. 123-139, 2003.
WILLER, H.; LERNOUD, J.; KILCHER, L. (Ed.). The world of organic agriculture: statistics and emerging trends 2013. Frick, Switzerland: Research Institute of Organic Agriculture (FiBL) \& Bonn: International Federation of Organic Agriculture Movements (IFOAM), 2013. Available at: <https://www.fibl.org/ fileadmin/documents/shop/1606-organic-world-2013. pdf $>$. Accessed at: 29 july 2015.

ZEHNDER, G.; GURR, G. M.; KÜHNE, S.; WADE, M. R.; WRATTEN, S. D.; WYSS, E. Arthropod pest management in organic crops. Annual Review Entomology, Stanford, v. 52, n. 1, p. 57-80, 2007. 
